\section{Muc5ac mucin expression during rat skin development}

\author{
V. Ferretti, ${ }^{1}$ A. Segal-Eiras, ${ }^{1}$ \\ C.G. Barbeito, ${ }^{2}$ M.V. Croce $^{1}$ \\ ${ }^{1}$ Centre of Basic and Applied \\ Immunological Research, Faculty \\ of Medical Sciences, National University \\ of La Plata \\ ${ }^{2}$ Cathedra of Histology and Embryology, \\ Faculty of Veterinary Sciences, National \\ University of La Plata, Argentina
}

\section{Abstract}

Some mucin genes have been detected during human embryonic and fetal organ development; however, little is known about mucin expression in epidermal development, neither in humans nor in other species. The present research was developed to explore Muc5ac skin expression during pre- and post-natal rat development. Immunohistochemistry (IHC), Western blotting (WB) and RT-PCR were employed. By IHC, Muc5ac protein was found early in embryonic epidermis from day 13 of gestation until seven days after birth when the surface epidermis became negative and the reaction was restricted to secreting sebum cells. In coincidence with IHC findings, WB analysis showed a band at approximately $200 \mathrm{KDa}$ at the same periods of development. Results were also confirmed by RT-PCR.

Muc5ac expression in rat embryonic epidermis suggests that Muc5ac may play a protective role in embryonic skin previous to birth which may be replaced by pile covering. To our knowledge, this is the first report that confirmed Muc5ac expression during skin development.

\section{Introduction}

The skin is the largest organ in the mammal body and serves as the first line of defense against external agents. During epidermal development, a single layer of epithelial cells is converted into multiple layers of terminally differentiating cells that continuously migrate outward and are shed from the body surface. This tissue architecture is precisely maintained and renewed throughout life.

Mucins are large, highly 0-glycosylated glycoproteins implicated in the protection of surface epithelia. ${ }^{2,3}$ The Muc5ac is a large soluble mucin gel-forming which is part of the protective layer of mucus covering gastrointestinal and airways epithelia. ${ }^{2}$ It is common knowledge that normal skin exhibits a rather restricted expression of mucins, and it has been demonstrated that epithelial cells of the normal epidermis do not express sialomucins while Muc5ac expression in cancer epidermal cells is well documented. ${ }^{4,5}$ On the other hand, little is known about mucin expression in epidermal development, neither in humans nor in other species. However, some mucin genes have been detected during human embryonic and fetal organ development according to differential expression patterns in comparison with adult tissues.,

The present research was developed to explore Muc5ac skin expression during preand post-natal rat development.

\section{Materials and Methods}

\section{Animals and samples}

A total of 160 animals were included in this study: 64 rat embryos and fetuses were collected at 13-20 days of gestation (stages D13-D20) from pregnant females (WKAH/Hok), neonates of $2,3,4,5,6,7,8,9,10$ and 15 post-natally days (2PD - 15PD) and adults of 10-12 weeks; 8 individuals from each stage of development were included. Eight skin samples belonging to each development stage were examined and scored.

This investigation was carried out in accordance with the Guide for the Care and Use of Laboratory Animals published by the Institute for Laboratory Animal Research (Washington DC, USA, 2011).

\section{Samples of embryos and fetuses processing}

Embryos and fetuses were obtained by laparotomy and hysterectomy of the pregnant females. The number of breeding in each gestation, which were processed and studied, ranged from 4 to 12 .

After the extirpation of the embryonic sac, the whole embryos and fetuses were separated according to further programmed analysis. ${ }^{7}$ For immunohistochemistry (IHC), animals were washed with $0.01 \mathrm{M}$ saline phosphate buffer $\mathrm{pH} 7.4$ (PBS) and fixed in 10\% (v/v) formaldehyde solution for $3 \mathrm{~h}$. To prepare the homogenates, the skin specimens were placed in cold PBS, pH 7.4 and immediately transferred to lysis buffer containing 0.01M TRIS$\mathrm{HCl}, \mathrm{pH} 7.4$ and $0.01 \mathrm{M}$ phenylmethylsulfonylfluoride (PMSF; Sigma-Aldrich, St. Louis, MO, USA), in a ratio of $4 \mathrm{~mL} / \mathrm{g}$ for subsequent homogenization. To analyze mRNA expression, skin samples were placed in RNAlater ${ }^{\circledR}$ (Invitrogen, Carlsbad, CA, USA).
Correspondence: Prof. María Virginia Croce, Centre of Basic and Applied Immunological Research, Faculty of Medical Sciences, National University of La Plata, Avenida 7 877, La Plata, Buenos Aires, Argentina.

Tel. +54.221.4236711 ext 342 - Fax: +54.221.4258989.

E-mail: crocevir@hotmail.com

Key words: Muc5ac, skin, rat, development.

Conflict of interest: the authors declare that they have no financial relationship that may lead to a conflict of interest in relation to this manuscript.

Contributions: VF, experiments performing; VF, MVC, manuscript writing. All authors participated in the design, interpretation of the studies and analysis of the data and review of the manuscript.

Acknowledgements: we gratefully acknowledge the generous help of Dr. Martín C. Abba for assistance with RT-PCR analysis and Mr. Juan Carlos Molina and Mr. Ruben Mario for technical assistance.

Funding: this study was supported by the National University of La Plata, Argentina.

Disclosure: Prof. María Virginia Croce is member of the research career of the Comisión de Investigaciones Científicas de la Provincia de Buenos Aires (CIC/PBA).

Received for publication: 21 November 2014. Accepted for publication: 7 January 2015

This work is licensed under a Creative Commons Attribution NonCommercial 3.0 License (CC BYNC 3.0).

(C) Copyright V. Ferretti et al., 2015

Licensee PAGEPress, Italy

European Journal of Histochemistry 2015; 59:2462 doi:10.4081/ejh.2015.2462

\section{Samples of neonates and adults} processing

Neonates and adults were dissected and the skin samples were separated. Each sample was sectioned to cover different programmed studies: a piece was fixed in $10 \%(\mathrm{v} / \mathrm{v})$ formaldehyde solution for immunohistochemical analysis, another piece was included in lysis buffer for subsequent homogenization, and finally, a third piece was placed in RNAlater ${ }^{\circledR}$ (Invitrogen) for subsequent analysis of mRNA expression.

\section{Antibodies}

An anti-human MUC5AC mouse monoclonal antibody (MAb) was used (45M1, IgG1, culture supernatant), ${ }^{8}$ which was previously tested in adult rat tissue. The corresponding epitopes 
are encoded by the Muc5ac gene. The 45M1 epitope has been located in the cys9 domain of the C-terminal region of the MUC5AC apomucin. ${ }^{9}$ Two antibodies were used to recognize different types of epidermal cells, 3H2061 (Santa Cruz Biotechnologies, Santa Cruz, CA, USA), a mouse monoclonal anti-human cytokeratin 5/6/18 and EP1024Y (Abcam, Cambridge, UK), rabbit monoclonal antibody raised against human MUC1.

\section{Immunohistochemical analysis}

IHC was performed according to standard procedures as reported in previous studies. ${ }^{10}$ Briefly, immunodetection was performed with the Dako Cytomation LSAB+System-HRP (Dako, Glostrup, Denmark). Finally, sections were counterstained with hematoxylin (Sigma), dehydrated and coverslipped with mounting media. Samples were evaluated under light microscope and the percentage of cells positively stained in one sample was quantified: $0-5 \%=0 ; 5-30 \%=1 ; 31-60 \%=2$ and $61-100 \%=3$. The patterns of reaction were: $\mathrm{L}$, linear membrane; C, cytoplasmic; and M, mixed, linear and cytoplasmic. Staining intensity was scored in a semi quantitative manner and was graded as: -, negative; + , low; ++, moderate; and +++, strong.

\section{Preparation of homogenates}

Homogenates were obtained from embryonic, fetal, neonatal and adult rat skin specimens as previously reported. ${ }^{11}$ Protein concentration was measured by Bradford assay (Bio-Rad Laboratories, Hercules, CA, USA) to achieve the same protein amount in each assay and samples were stored at $-70^{\circ} \mathrm{C}$.

\section{SDS-PAGE and Western blot}

Homogenates that contained $50 \mu \mathrm{g}$ total protein were diluted in $25 \%$ SDS and $10 \%$ glicerol and heated at $90^{\circ} \mathrm{C}$ for $5 \mathrm{~min}$ and separated on a 4-6\% mini gels and blotted onto nitrocellulose transfer membranes (Schleicher and Schuell). Membranes were incubated with $45 \mathrm{M} 1 \mathrm{MAb}(1 \mu \mathrm{g} / \mathrm{mL})$ at $4{ }^{\circ} \mathrm{C}$ overnight followed by horseradish peroxidase (HRP)-conjugated goat anti-mouse IgG antibody (Dako) (1:1000); protein bands were detected by autoradiography. The corresponding negative controls were included in the absence of primary antibody.

\section{RT-PCR analysis of Muc5ac mRNA}

Total RNA was isolated from embryonic, fetal and adult skin samples using TRIZOL Reagent ${ }^{\circledR}$ (Invitrogen) following the manufacturer's protocols. RNA integrity was assessed by electrophoresis in $1.5 \%$ agarose formaldehyde denaturing minigel. Before RT-PCR, the RNA samples were treated with DNAse I (1 U/L) (Fermentas Life Sciences, Burlington, Ont., Canada). The cDNAs were synthesized using SuperScript ${ }^{\mathrm{TM}}$ First-strand Synthesis System (Invitrogen, USA) and measured using a NanoDrop Spectrophotometer ${ }^{\circledR} 2000$. For mRNA expression analysis, $500 \mathrm{ng}$ of total cDNA for each sample was employed. RNA 18S was used as reference.

The following primers were used: Muc5ac Forward, 5 -AACTCTGCCCACCACAAGC-3, Muc5ac Reverse, 5 - ATTGGACTGATTGGATAGATGGCA-3, designed against the rat mRNA Muc5ac sequence XM_001063331.5:12 RNA18s Forward, 5 -GTAACCCGTTGAACCCCATT -3, RNA18s Reverse, 5 -CCATCCAATCGGTAGTAGCG-3.$^{13}$ Muc5ac and RNA18s product sizes are 149 and $151 \mathrm{bp}$, respectively. Thermal profile was programmed as follows: Muc5ac, an initial denaturation step of $3 \mathrm{~min}$ at $95^{\circ} \mathrm{C}$ followed by 45 cycles of $20 \mathrm{~s}$ at $94^{\circ} \mathrm{C}, 20 \mathrm{~s}$ at $65^{\circ} \mathrm{C}$ and $20 \mathrm{~s}$ at $72^{\circ} \mathrm{C}$ and a final extension at $72^{\circ} \mathrm{C}$ for $2 \mathrm{~min}$; RNA18s, at an initial denaturing step of $2 \mathrm{~min}$ at $94^{\circ} \mathrm{C}$ followed by 35 cycles of $40 \mathrm{~s}$ at $94^{\circ} \mathrm{C}, 50 \mathrm{~s}$ at $50^{\circ} \mathrm{C}$ and $30 \mathrm{~s}$ at $72^{\circ} \mathrm{C}$ and a final extension at $72^{\circ} \mathrm{C}$ by $5 \mathrm{~min}$. Detection of the amplified fragments was made by electrophoresis onto $8 \%$ polyacrylamide gels and silver staining. These experiments were performed in triplicate. The corresponding negative controls were included using $\mathrm{H}_{2} 0$ instead of cDNA sample.
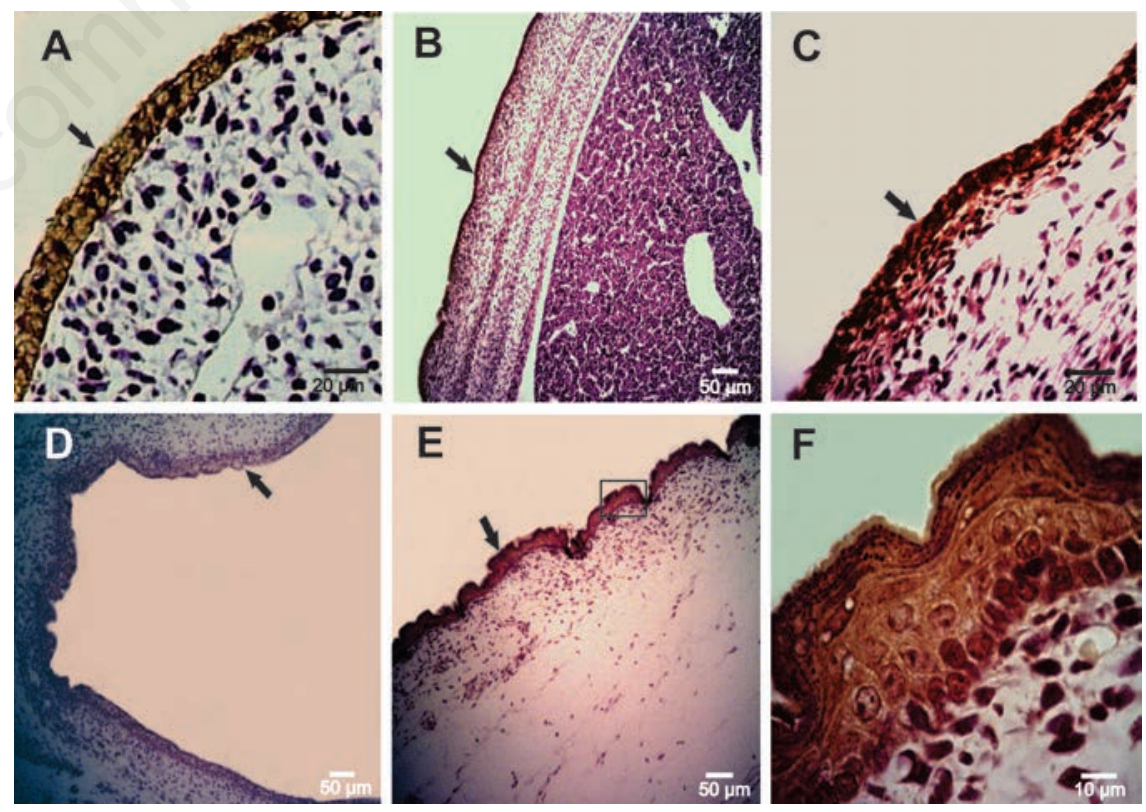

Figure 1. Immunohistochemical staining of Muc5ac in rat embryonic epidermis employing anti-MUC5AC MAb, 45M1. A) An embryonic epidermis at 13 days of gestation shows a moderate cytoplasmic reaction. B, C) Epidermis at 16 days of gestation depicts an increased staining. D) Epidermis at 18 days of gestation. E) Epidermis at 20 days of development. F) Magnification of the box in panel $\mathrm{E}$. Black arrows indicate the positive reaction. 
Figure 4 B-D). The reaction was low in neonates and moderate in adults.

To further characterize rat skin Muc5ac, SDS-PAGE and WB were employed. In accordance to IHC results, a variation of expression was found. Embryonic samples showed a band at approximately $200 \mathrm{kDa}$ between 17 and 20 days before birth (Figure 5A) while neonatal skin samples showed a strong intensity of reaction at early days post-birth and a lower intensity at 10PD (Figure 5B). In order to analyze mRNA Muc5ac expression in rat skin, cDNA samples were obtained at different gestational ages and RT-PCR analysis was performed. All cases showed an amplified of $\sim 149$ bp (Figure 6).

\section{Discussion}

In this study, we analyzed Muc5ac expression in rat skin samples employing a monoclonal antibody against the $\mathrm{C}$-terminal region of the human MUC5AC apomucin. Human MUC5AC was first cloned from tracheobronchial and stomach cDNA libraries while rat Muc5ac gene was cloned by Inatomi et al. ${ }^{14}$ from conjunctival goblet cells and stomach mucosal epithelia. MUC5AC expression in epidermal cells has been associated to certain skin conditions such as extra-mammary Paget $s$ disease, a rare epidermal carcinoma. ${ }^{5,15}$ In consequence, the interest of MUC5AC has been mainly focused on their functions in carcinogenesis and the possibility of its employment as a tumor marker. In contrast, its expression in normal skin and furthermore its role in skin development remains unexplored.

In embryonic epidermis, we demonstrated by IHC rat Muc5ac expression from D13. The reaction was restricted to epidermal cells covering the embryo's body. At this stage, the rat skin consists in 3-5 layers of undifferentiated cells. From D16 until birth, a very rapid epidermal proliferation occurs and the undifferentiated epithelium becomes a cornified multilayered epithelium, which is in coincidence with the higher intensity of Muc5ac expression in embryonic epidermis. The MUC5AC/Muc5ac cytoplasmic pattern found in our present analysis is in coincidence with our previous report, ${ }^{1}$ in which the MAb $45 \mathrm{M} 1$ was used to perform an exhaustively analysis in order to identify and localize the Muc5ac in different tissues of diverse mammalian species. A strong cytoplasmic reaction was found in adult surface gastric epithelium of rat, cat, rabbit, pig, and cow specimens as well as goblet cells from upper and lower mammalian respiratory tract. Other authors also found a cytoplasmic pattern in human specimens; Biemer-
Hüttmann et al. ${ }^{16}$ found in human normal colon specimens Muc5ac cytoplasmic staining. It is possible that the cytoplasmic reaction that we have found both in embryonic skin cells as well as in neonate and adult sebum secreting cells may be due to the high Muc5ac synthesis which would be visualized at the whole cytoplasm. Following the model proposed by Sheehan et al. ${ }^{17}$ for HT29 cell line in culture, the biosynthetic Muc5ac process would develop in the endoplasmic reticulum. There, the mucin forms disulfide-linked dimera via their $\mathrm{C}$ termini, then, GalNac addition occurs in the end endoplasmic reticulum/Golgi; thereafter, the glycan would be elaborated with the fully glycosylation of the dimers, which multimerize via disulfide linkage between their N-termini.

On the other hand, we found an intense reaction in several layers of the epidermis of the neonatal skin between 2PD and 6PD, and surprisingly, also sebaceous glands were positive. These structures are originating as prominences associated to developing hair follicles and appear during the first week of life in rats and mice. ${ }^{18}$ At $7 \mathrm{PD}$, the epidermis became negative and the reaction was restricted to sebaceous cells, which is similar to adult expression. The absence of rat Muc5ac expression in epidermis was coincident with hair appearance. In consequence, and taking into account that MUC5AC role is mainly protective $^{2}$, it may be suggested that at prenatal

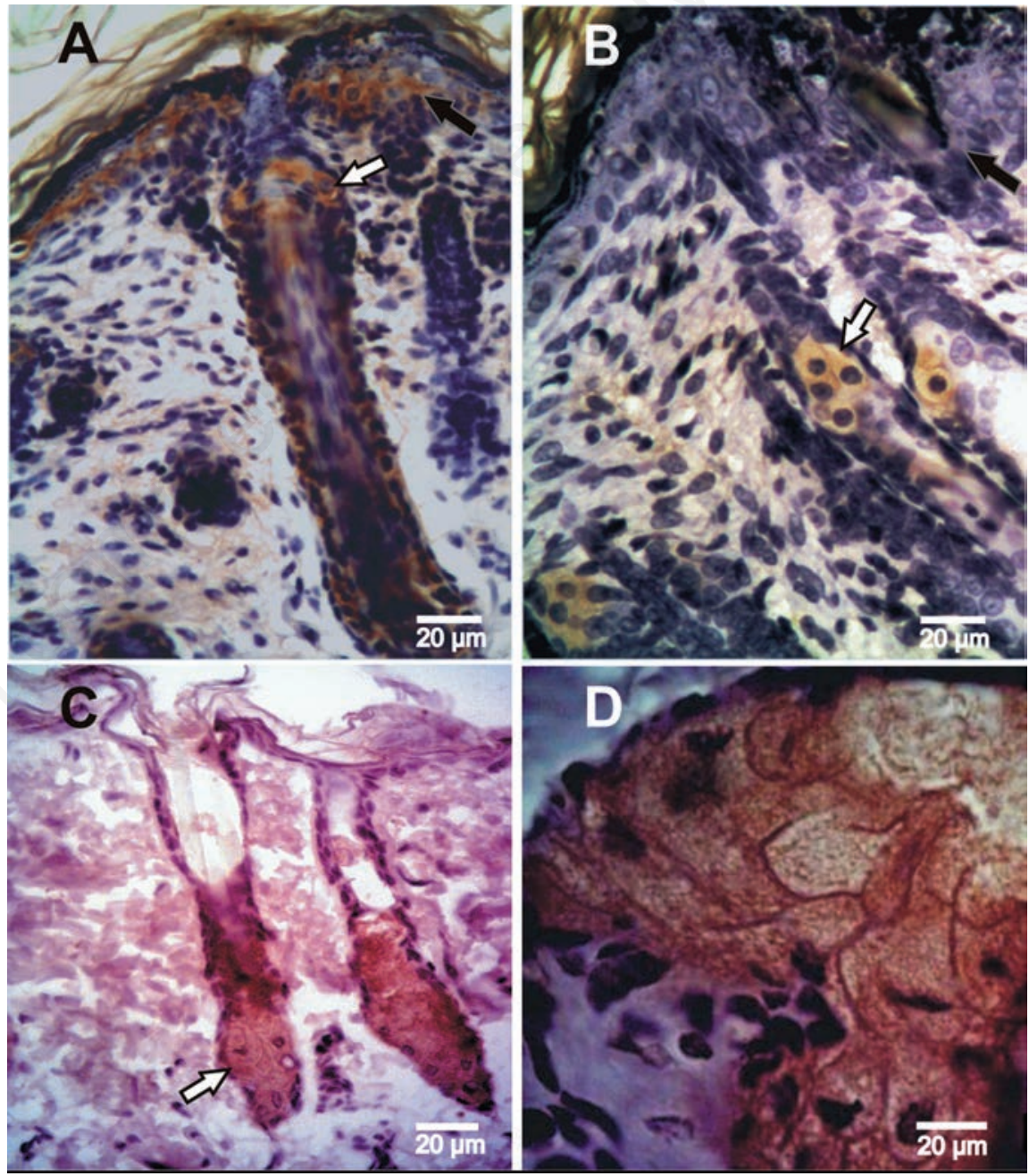

Figure 2. Expression of Muc5ac determinates using immunohistochemistry in rat skin of neonates and adults. A) Epidermis at 4 post-natal days; the reaction is observed at the epidermis, hair follicle and sebaceous gland. B) Epidermis at 7 days after birth, in which the reaction is restricted to the secreting sebum cells. C, D) Adult skin showing the positive reaction in the sebaceous gland and the negative epidermis. Black arrows indicate the positive epidermis and white arrows indicate the sebaceous gland showing positive expression. 
stages, skin rat Muc5ac could behave as a protection against possible damage agents, such as amniotic fluid. Probably, after birth, this protective function would be assumed by hair coating. Zhang et al. ${ }^{19}$ have studied another mucin, MUC4, and they found its significant staining on the stratified epithelium in the early human embryo and also their absence in adult skin. They suggested that MUC4 would play a protective role during a specific stage of development which is not later required since epithelial differentiation occurs. At present, in the case of MUC5AC/Muc5ac, there is no information about its expression during embryologic development; furthermore, Muc5ac expression in normal adult skin is scarce and most authors consider that MUC5AC is not expressed in normal adult epidermis. However, the protective role of the Muc5ac mucin in other tissues such as gastric mucosa and airways has been postulated by several authors. ${ }^{2,20,21}$

In order to identify sebum cells at different stages of development, in embryonic, neonate and adult specimens, cytokeratins $5 / 6$ and Mucl expression was analyzed. These antigens constitute good markers of secreting sebum cells, and it is known that cytokeratins $5 / 6$ are expressed on squamous epithelium
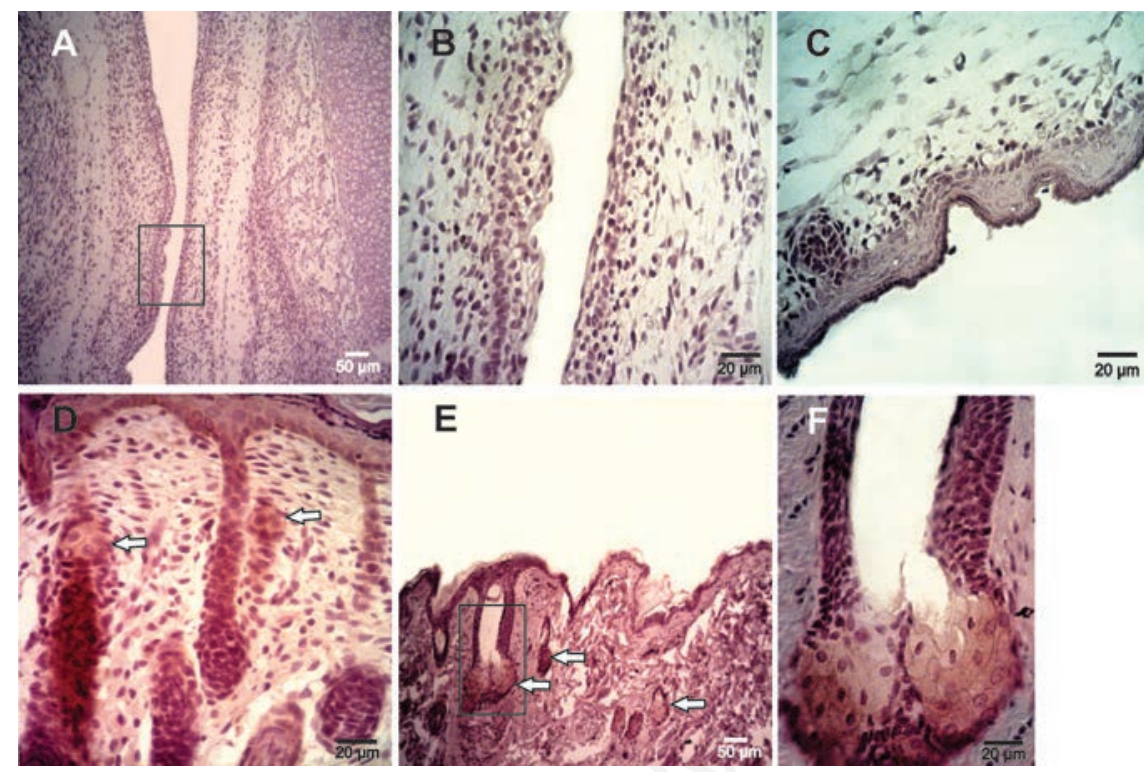

$E$

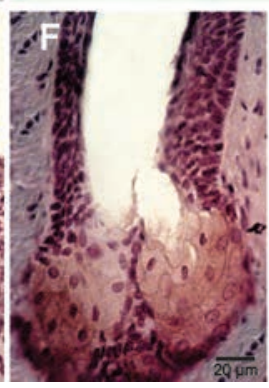

Figure 3. Immunohistochemical findings employing anti-ck 5/6/18 Mab, EP1024Y. A) Epidermis at 16 days of gestation; no positive reaction was observed. B) Enlarged image of the box in panel A. C) Epidermis at 20 days of development without cytokeratin 5/6 expression; in this picture, a developing hair follicle shows a negative reaction. D) Epidermis at 5 post-natal days; a reaction was restricted to basal keratinocytes and secreting sebum cells. E) Adult epidermis showing the positive reaction at the sebaceous glands. F) Magnification of the box in panel $\mathrm{E}$. White arrows indicate the sebaceous gland showing positive expression.

Table 1. Immunohistochemical results of Muc5ac expression in embryonic, fetal, neonatal, and adult rat skin.

Positive cases/ Specific localivation
total cases Intensity of reaction

Stages of development embryos and fetuses

(days of gestation)

\begin{tabular}{|c|c|c|c|c|}
\hline D13 & $6 / 8$ & + & - & ++ \\
\hline D14 & $7 / 8$ & + & - & ++ \\
\hline D15 & $7 / 8$ & + & - & ++ \\
\hline D16 & $5 / 8$ & + & - & ++ \\
\hline D17 & $6 / 8$ & + & - & ++ \\
\hline D18 & $7 / 8$ & + & - & +++ \\
\hline D19 & $6 / 8$ & + & - & +++ \\
\hline D20 & $5 / 8$ & + & - & +++ \\
\hline
\end{tabular}

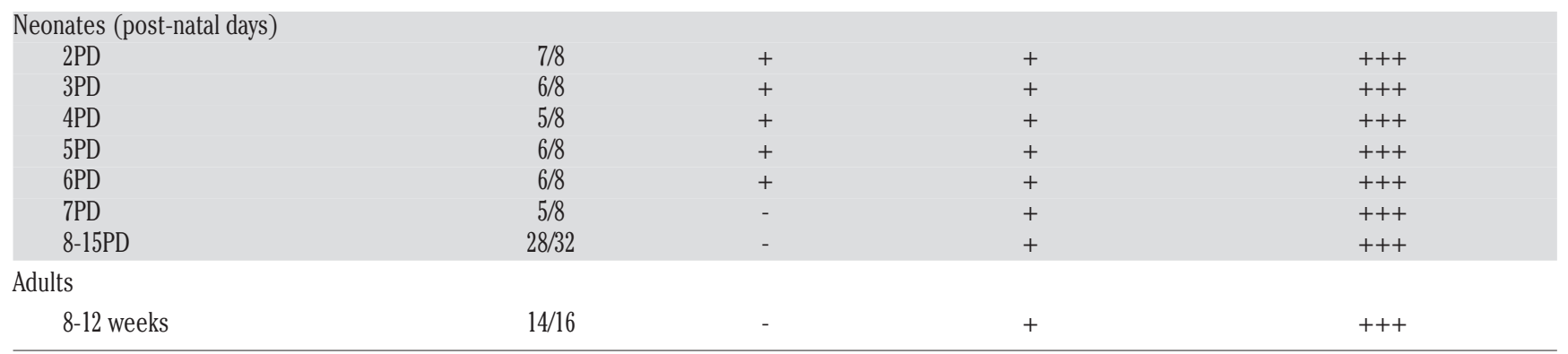

- , negative; +, low; ++, moderate; +++, strong. 
basal cells while Muc1 may be reactive on some of them..$^{22,23}$ In our study, both markers were found only in post-natally skin at sebaceous gland and in some cases at basal keratinocytes. Our results show that cytokeratins $5 / 6$ and Muc1 were expressed at sebum glands and at some basal keratinocytes belonging to neonate and adult specimens while neither Muc1 nor cytokeratins 5/6 were detected on embryonic epidermis. These interesting findings constitute an advance on elucidating antigenic expression on skin rat since Mucl and Muc5ac are expressed early after birth and they would be related to complete development of sebum glands although do not indicate a relationship between Muc5ac embryonic positive cells and those giving rise to adult sebum cells.

The results here obtained by IHC were confirmed by SDS-PAGE/WB analysis; in all positive cases, a band at approximately $200 \mathrm{kDa}$ was detected. In most reports SDS-PAGE/WB have been employed to obtain, identify and determine mucin molecular weights, including human MUC5AC, ${ }^{24}$ and Muc5ac in rats. ${ }^{25}$ In a previous report, ${ }^{11}$ as well as the results presented here, we found that the MUC5AC/Muc5ac MW is about $200 \mathrm{kDa}$, which are in coincidence with the results obtained by Reis et al. ${ }^{24}$ They have intensively studied MUC5AC and, employing SDS-PAGE found that the MW of MUC5AC was >200 kDa. Furthermore, Mata et al. ${ }^{25}$ studied a rat model and employed 8\% SDS-PAGE; they detected Muc5ac at a MW of $213 \mathrm{kDa}$ using MAb 45M1 (the same as we employed). Also in rat systems, lung homogenates, Xiao et al. ${ }^{26}$ and Ning et $a .^{27}$ employed SDS-PAGE/WB to identify Muc5ac at $10 \%$ and $8 \%$, respectively. Other reports employed agarose gels to identify MUC5AC, ${ }^{28,29}$ which may be also useful to detect particular molecular intermediates. ${ }^{17}$ Neonatal skin samples showed a strong intensity of reaction at early days post-birth with a gradual decline at 10PD. Furthermore, all the analyzed cDNA samples of embryonic, fetal, neonatal, and adult skin showed mRNA Muc5ac expression. It is known that mucins are produced by all epithelial cells, although the combination and relative amount of individual mucins vary by cell and tissue type. In a system also derived from the surface epithelium, which include adult epithelia of cornea and conjunctiva, it has been described the production of MUC5AC, MUC1, MUC4 and MUC16. MUC5AC is synthesized by conjunctival goblet cells while MUC1 is produced by corneal and conjunctival epithelia, MUC4 mainly by the conjunctiva, and MUC16 is found at apical corneal epithelial cells and at the lacrimal gland ductal epithelium, accessory lacrimal glands, and nasolacrimal duct epithelium. ${ }^{30}$ In another system, the mucins produced
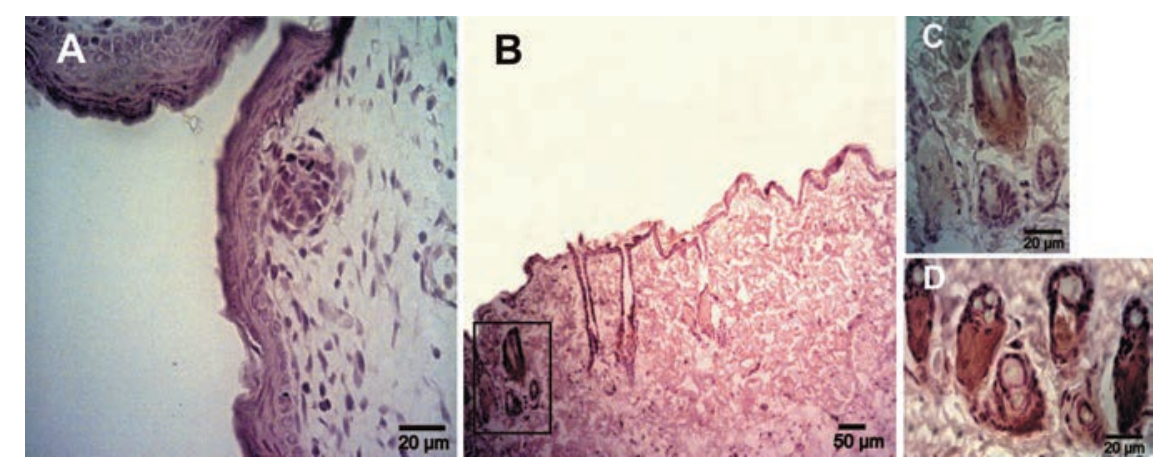

Figure 4. Expression of Muc1 determinates using immunohistochemistry in rat skin samples of embryos and adults. A) Epidermis at 20 days of gestation showing a negative reaction. B) Adult skin; the reaction was restricted to the sebaceous glands. C) Magnification of the box in panel B. D) Sebaceous glands of adult skin showing a high Mucl expression.
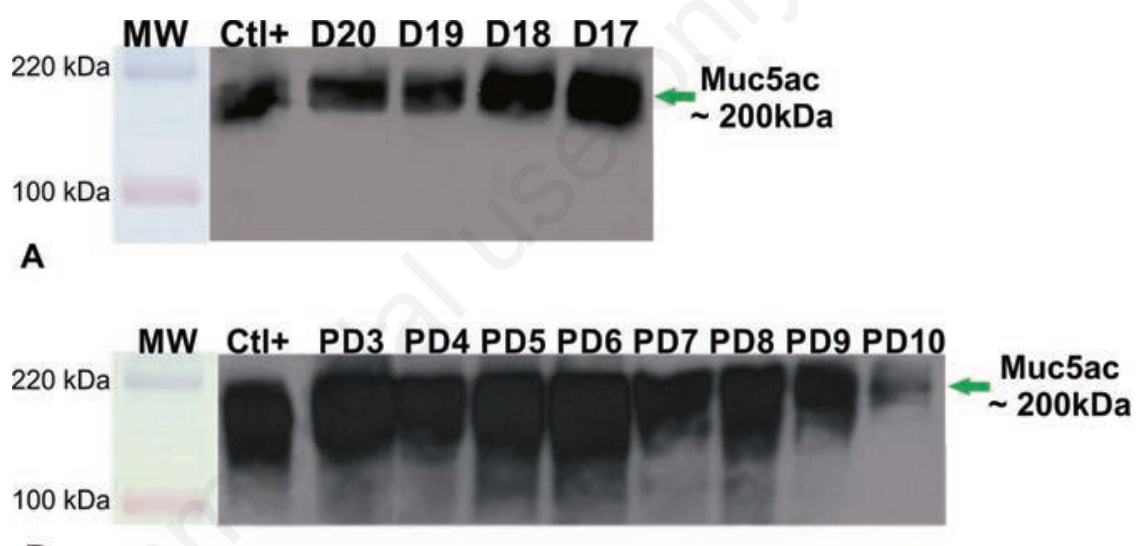

B

Figure 5. Western blot analysis employing anti-MUC5AC MAb, 45M1. Homogenates from epidermis belonging to fetuses at 20,19,18 and 17 days of gestation (A) and to neonates between 3-10 days post birth (B). All samples show a strong reaction band at about $200 \mathrm{kDa}$, a lower intensity at 10 days post birth is observed. $\mathrm{Ctl}+$, positive control.

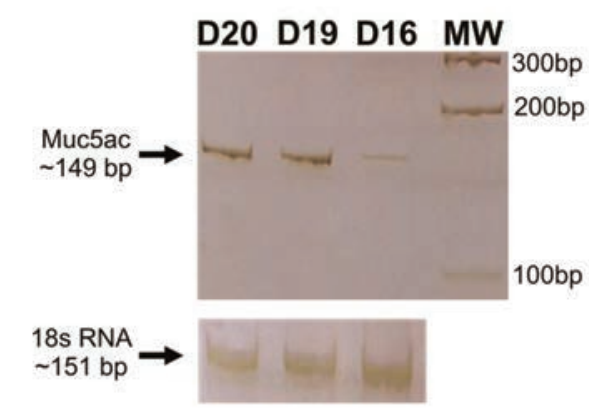

A

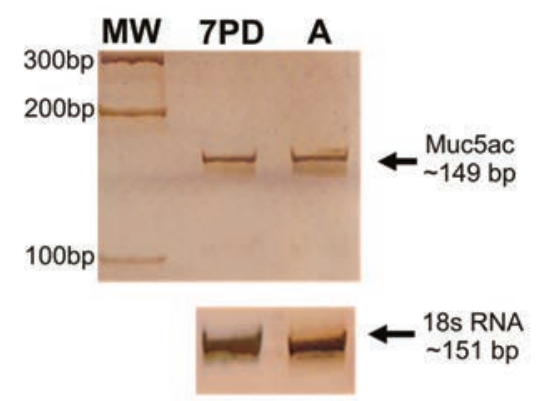

B

Figure 6. Muc5ac mRNA analysis using RT-PCR of skin rat embryos at D16, D19 and D20 days of gestation (A) and neonates at 7 days post birth and adults (B); a band about $149 \mathrm{bp}$ is detected in all samples; RNA was used as normalizer. MW, standard of molecular weight pGEM1 (Promega, Madison, WI, USA). 
in the adult human airway epithelium are MUC5AC and MUC5B, 90\% and MUC1, MUC4 and MUC16, 10\%. MUC5AC is produced by goblet cells while ciliated cells synthesize MUC1, MUC4 and MUC16, and mucus gland cells produce MUC5B and MUC16. ${ }^{31-33}$

The fact that Muc5ac is expressed in rat embryonic epidermis and in post-natal and adult sebum cells of hair associated glands, let us to hypothesize that Muc5ac may play a protective role in embryonic skin previous to birth which may be replaced by pile covering. As MUC5AC has been implicated in human skin conditions, animal models would be important to clarify biological and medical aspects. To our knowledge, this is the first report that shows Muc5ac expression during skin development.

\section{References}

1. Watt FM. The stem cell compartment in human interfollicular epidermis. J Dermatol Sci 2002;28:173-80.

2. Rose MC, Voynow JA. Respiratory tract mucin genes and mucin glycoproteins in health and disease. Physiol Rev 2006;86:245-78.

3. Buisine MP, Desseyn JL, Porchet N, Degand P, Laine A, Aubert JP. Genomic organization of the 3 '-region of the human muc5ac mucin gene: additional evidence for a common ancestral gene for the 11p15.5 mucin gene family. Biochem $\mathrm{J}$ 1998;332:729-38.

4. Chakraborty S, Bonthu N, Swanson BJ, Batra SK. Role of mucins in the skin during benign and malignant conditions. Cancer Lett 2011;301:127-41.

5. Smith RF, Stern BH, Smith AA. Mucin immunohistochemistry in the diagnosis and mapping of extramammary Paget's disease. J Cell Mol Med 2008;12:1605-10.

6. Buisine MP, Devisme L, Copin M, DurandReville M, Gosselin B, Aubert JP Developmental mucin gene expression in the human respiratory tract. Am J Res Cell Mol Biol 1999;20:209-18.

7. Lacunza E, Ferretti VA, Barbeito C, SegalEiras A, Croce MV. Immunohistochemical evidence of Mucl expression during rat embryonic development. Eur J Histochem 2010;54:e49.

8. Bara J, Gautier R, Mouradian P, Decaens C, Daher N. Oncofetal mucin ml epitope family: characterization and expression during colonic carcinogenesis. Int $\mathrm{J}$ Cancer 1991;47:304-10.
9. Lidell ME, Bara J, Hansson GC. Mapping of the $45 \mathrm{ml}$ epitope to the c-terminal cysteine-rich part of the human MUC5AC mucin. FEBS J 2008;275:481-9.

10. Croce MV, Isla-Larrain MT, Rua CE, Rabassa ME, Gendler SJ, Segal-Eiras A. Patterns of Mucl tissue expression defined by an anti-MUC1 cytoplasmic tail monoclonal antibody in breast cancer. J Histochem Cytochem 2003;51:781-8.

11. Lacunza E, Bara J, Segal-Eiras A Croce MV. Expression of conserved mucin domains by epithelial tissues in various mammalian species. Res Vet Sci 2009;8:68-77.

12. Li R, Meng Z, Xie J. Effects of sulfur dioxide on the expressions of MUC5AC and ICAM-1 in airway of asthmatic rats. Regul Toxicol Pharmacol 2007;48:284-91.

13. Schmittgen TD, Zakrajsek BA. Effect of experimental treatment on housekeeping gene expression: validation by real-time, quantitative RT-PCR. J Biochem Biophys Methods 2000;46:69-81.

14. Inatomi T, Tisdale AS, Zhan Q, SpurrMichaud S, Gipson IK. Cloning of rat muc5ac mucin gene: comparison of its structure and tissue distribution to that of human and mouse homologues. Biochem Biophys Res Comm 1997;236:789-97.

15. Yoshii N, Kitajima S, Yonezawa S, Matsukita S, Setoyama M, Kanzaki T. Expression of mucin core proteins in extramammary Paget's disease. Pathol Int 2002;52:390-9.

16. Biemer-Hüttmann A, Walsh MD, McGuckin MA, Ajioka Y, Watanabe H, Leggett BA, et al. Immunohistochemical staining patterns of MUC1, MUC2, MUC4, and MUC5AC mucins in hyperplastic polyps, serrated adenomas, and traditional adenomas of the colorectum. J Histochem Cytochem 1999;47:1039-44.

17. Sheehan JK, Kirkham S, Howard M, Woodman P, Kutay S, Brazeau C, et al. Identification of Molecular Intermediates in the Assembly Pathway of the MUC5AC Mucin. J Biol Chem 2004;279:15698-705.

18. Fluhr JW, Mao-Qiang M, Brown BE, Hachem JP, Moskowitz DG, Demerjian M, et al. Functional consequences of a neutral $\mathrm{pH}$ in neonatal rat stratum corneum. $\mathrm{J}$ Invest Dermatol 2004;123:140-51.

19. Zhang Yasin M, Carraway CA, Carraway KL. MUC4-4 expression and localization in gastrointestinal tract and skin of human embryos. Tissue Cell 2006;38:271-5.

20. Thornton DJ, Sheehan JK. From mucins to mucus: toward a more coherent understanding of this essential barrier. Proc Am Thorac Soc 2004;1:54-61.
21. Ehre C, Worthington EN, Liesman RM, Grubb BR, Barbier D, O'Neal WK, et al. Overexpressing mouse model demonstrates the protective role of Muc5ac in the lungs. Proc Natl Acad Sci USA. 2012; 109: 16528-33.

22. Chu PG, Weiss LM. Keratin expression in human tissues and neoplasms. Histopathology 2002; 40:403-39.

23. Fuertes L, Santonja C, Kutzner H, Requena L. Immunohistochemistry in dermatopathology: a review of the most commonly used antibodies (part I). Actas Dermosifiliogr 2013;104:99-127.

24. Reis C, David L, Nielsen P, Clausen H, Mirgorodskaya K, Roepstorff $\mathrm{P}$, et al. Immunohistochemical study of MUC5AC expression in human gastric carcinomas using a novel monoclonal antibody. Int $\mathrm{J}$ Cancer 1997; 74:112-21.

25. Mata M, Ruíz A, Cerdá M, Martinez-Losa M, Cortijo J, Santangelo F, et al. Oral Nacetylcysteine reduces bleomycin-induced lung damage and mucin Muc5ac expression in rats. Eur Respir J 2003;22:900-5.

26. Xiao J, Wang K, Feng Y, Chen X, Xu D, Zhang M. Role of extracellular signal regulated kinase $1 / 2$ in cigarette smoke-induced mucus hypersecretion in a rat model. Chin Med J 2011;124:3327-33.

27. Ning Y, Shang Y, Huang H, Zhang J, Dong $\mathrm{Y}, \mathrm{Xu} \mathrm{W}$, et al. Attenuation of cigarette smoke-induced airway mucus production by hydrogen-rich saline in rats. PLosOne 2013;8:e83429.

28. Vincent A, Perrais M, Desseyn J-L, Aubert J-P, Pigny P, Van Seuningen I. Epigenetic regulation (DNA methylation, histone modifications) of the 11p15 mucin genes (MUC2, MUC5AC, MUC5B, MUC6) in epithelial cancer cells. Oncogene 2007;26: 6566-76.

29. Spurr-Michaud S, Argüeso P, Gipson I. Assay of mucins in human tear fluid. Exp Eye Res 2007;84:939-50.

30. Gipson IK. The ocular surface: the challenge to enable and protect vision: the Friedenwald lecture. Invest Ophthalmol Vis Sci 2007;48:4391-8.

31. Sheehan JK, Kesimer M, Pickles R. Innate immunity and mucus structure and function. Novartis Found Symp 2006;279:15566 discussion 167-9, 216-9.

32. Hatrupp Ch, Gendler SJ. Structure and function of the cell surface (tethered) mucins. Annual Rev Physiol 2008;70:431-57.

33. Thornton DJ, Rosseau K, McGuckin M. Structure and function of the polymeric mucins in airways mucus. Annual Rev Physiol 2008;70:459-86. 